\title{
STOSUNKI FRANCUSKO-ANDORSKIE W DWUDZIESTOLECIE PODPISANIA TRAKTATU O DOBRYM SĄSIEDZTWIE, PRZYJAŹNI I WSPÓLPRACY ${ }^{1}$
}

Współcześnie Księstwo Andory stanowi przedmiot badań nadal niewielu opracowań politologicznych. Najczęstszym przedmiotem zainteresowania jest wyjątkowa na skalę światową formuła dwuosobowej głowy państwa (tj. diarchii), którą z urzędu są każdorazowo: prezydent Republiki Francuskiej oraz biskup hiszpańskiej diecezji Seo de Urgell.

Swego rodzaju odrodzenie się państwowości andorskiej, do którego doszło w 1993 r., miało swoje źródła w często przywoływanej procedurze przyjmowania pierwszej w dziejach Księstwa konstytucji. Jednak dużo mniejsza uwaga badaczy skupiona jest na podpisanym w tym samym roku traktacie, który, zdaniem autora, miał równie ważne znaczenie dla dzisiejszej pozycji prawnomiędzynarodowej (ale też i wewnętrznego porządku politycznego) pirenejskiego księstwa. Przedmiotem niniejszego artykułu będzie zweryfikowanie powyższej hipotezy, a także odpowiedzenie na pytanie o rolę, jaką odegrały stosunki Andory z Francją na przestrzeni kilkuset lat dla obecnego statusu międzynarodowego Księstwa, jak i dla jego systemu politycznego. Stosunki Andory z Francją jako państwem członkowskim Unii Europejskiej mają swój skutek głównie w kwestiach związanych z walutą europejską, wobec czego aspekt ten będzie również przedmiotem niniejszego artykułu.

\section{UWARUNKOWANIA HISTORYCZNE STOSUNKÓW ANDORY Z FRANCJĄ}

Dość powszechnie wskazuje się, że Andora powstała jako podmiot polityczny w 1278 r., kiedy to doszło do zawarcia tzw. pierwszego traktatu arbitrażowego Pareatge (w literaturze termin ten funkcjonuje w wielu innych wersjach: Pariatge, Pariatje, Pairage) (Moses, 1893: 34). W 843 r. Karol Łysy określił Dolinę Andory jako terytorium, które będzie podlegało dziedziczeniu hrabiom z Urgell (Bladé, 1882: 13). W późniejszych latach doszło do serii konfliktów między francuskimi hrabiami Foix a miejscowym Kościołem katolickim. W połowie XIII wieku hrabiowie francuscy pod-

1 Traité de bon voisinage, d'amitié et de coopération. Środki finansowe na przygotowanie niniejszego artykułu pochodzą z Narodowego Centrum Nauki w ramach finansowania stypendium doktorskiego na podstawie decyzji numer DEC-2014/12/T/HS5/00140. 
jęli próbę przejęcia całkowitej władzy nad Dolina, co zostało jednak zahamowane przez interwencję królów aragońskich wspieranych przez papieży (Osóbka, 2009: 184).

8 września 1278 r. Pere d'Urg i Roger Bernat III de Foix podpisali porozumienie pokojowe znane w historii państwa jako Primer Pareatge d'Andorra. Układ ten został dekadę później potwierdzony przez papieża Marcina IV. W Pareatge poza zapisaniem obowiązku służby wojskowej względem obu panów, zobowiązano lud Andory do płacenia obu zarządcom specjalnej daniny (tzw. quèstii) płaconej co roku naprzemiennie. O ile kwota ustalona dla pana episkopalnego była stała, to francuski zarządca miał dowolne prawo ustalania wysokości składanej mu quèstii. Kwota ta była zmienna (por. tabela 1) (np. w 1939 r. wynosiła równowartość ówczesnych 25,44\$, a dwadzieścia lat później tylko 3,88\$). 1993 rok przyniósł koniec ponad siedemsetletniego okresu wasalnej zależności ludności Księstwa od dwóch współksiążąt (Andorra Pays France, 1959).

Tabela 1

Wysokość daniny płaconej współksięciu francuskiemu w wiekach XVII-XX

\begin{tabular}{||l|c|}
\hline \multicolumn{1}{|c|}{ Okres } & Wysokość \\
\hline XVII w. & 1870 liwrów barcelońskich \\
\hline Koniec XVIII w. & 1920 franków \\
\hline XIX w. & 960 franków \\
\hline Początek lat 90. XX wieku & 1920 franków \\
\hline
\end{tabular}

Źródło: Opracowanie własne na podstawie: Bladé, 1882: 21; Mateu, Luchaire, 1999: 22; Tribute, 1939.

Co istotne dla przedmiotu niniejszego artykułu, prawa senioralne (w odniesieniu do zarządcy francuskiego) przechodziły na kolejnych panów zgodnie z wewnętrznymi zasadami sukcesji. Dekadę po zawarciu traktatu arbitrażowego, ze względu na konflikt sprowokowany przez hrabiego Foix, doszło do podpisania drugiego traktatu. Na jego mocy andorska ludność została zobowiązana do składania przysięgi na wierność obu panom feudalnym (Osóbka, 2009: 184-185).

W 1589 r. wnuk Henryka II de Foix jako Henryk IV zasiadł na tronie Francji. Jego syn, Ludwik XIII, wstępując na tron w 1610 roku przeniósł na koronę francuską prawa domu Foix, dzięki czemu monarcha francuski otrzymał tytuł i prawa współksięcia Andory. Przeniesienie ośrodka władzy francuskiego współksięcia pozwoliło ludności andorskiej na większą samodzielność w rozwoju politycznym i gospodarczym Doliny. Francuski książę wskazał wówczas de Carenaya na odpowiedzialnego za wykonywanie wymiaru sprawiedliwości w Andorze (Kucała, 2007: 34).

$\mathrm{Na}$ stosunkach andorsko-francuskich pewne piętno odcisnęły wydarzenia Wielkiej Rewolucji. Wówczas to rząd republikańskiej Francji bezwzględnie odrzucił możliwość składania daniny przez Andorczyków. Quèstia zdaniem władz francuskich stanowiła rażący przykład znienawidzonego przez rewolucjonistów feudalizmu, który stanowił główną determinantę do wystąpienia przeciwko arystokracji i panującego ustroju 
społeczno-gospodarczego. Wbrew temu co mogłoby się wydawać, współksiążę nie ogłosił się wówczas samorządcą Andory, ale wsparł prośby Andorczyków, którzy zwrócili się do władz francuskich o powrót do stosunków sprzed rewolucji. Zostały one przywrócone dzięki decyzji samego Napoleona Bonaparte (Bladé, 1882: 24-27).

\section{STOSUNKI ANDORSKO-FRANCUSKIE I ICH WPLYW NA POLITYKE WEWNĘTRZNĄ KSIĘSTWA W XX WIEKU DO PRZYJĘCIA KONSTYTUCJI W 1993 ROKU}

Bez wattpienia najważniejsze wydarzenie pierwszej połowy XX wieku w historii Andory miało miejsce w 1933 r. Wówczas to ze względu na wtargnięcie do sali posiedzeń parlamentu domagających się reform młodych Andorczyków, na terytorium Księstwa wkroczyło 50 francuskich żandarmów (French 'invaders', 1933: 1; France sends, 1933: 1). Rok później Andorą wstrząsnęła próba przejęcia władzy przez rosyjskiego emigranta, Borysa de Skossyreffa Mawrusowa. W 1934 r. wydał on manifest, w którym ogłosił się zastępcą króla Francji i jedynym zarządcą Kraju Dolin, wypowiadając tym samym wojnę współksięciu episkopalnemu. W reakcji na manifest rząd hiszpański wysłał do Andory funkcjonariuszy policji, którzy aresztowali uzurpatora i przewieźli do Barcelony (Kaffka, 2009: 147-154).

Bardzo ciekawym okresem w historii Andory była II wojna światowa, która to zamknęła Kraj Dolin w kleszczu niedemokratycznych reżimów: generała Franco od zachodu i zależnego względem hitlerowskich Niemiec rządu Vichy od wschodu. W trakcie trwania wojny Andorczycy utracili przyznane w 1933 r. powszechne prawa wyborcze dla mężczyzn (Shephers 's, 1941). Andora, otrzymawszy od A. Hitlera gwarancję zachowania nienaruszalności jej terytorium podczas wojny, mogła zarówno podczas wojny, jak i po jej zakończeniu bardzo szybko rozpocząć proces przemian gospodarczych, politycznych i społecznych (Andorra receives, 1942). Liczba ludności, głównie emigrantów powojennych, rosła bardzo szybko. Prowadziło to pośrednio do rozwoju gospodarczego, politycznego i społecznego. Procesu demokratyzacji nie zahamowała utrata obu współksiążąt w 1969 r., kiedy to francuski prezydent Charles de Gaulle 28 kwietnia podał się do dymisji, a dzień później papież Paweł VI przyjął rezygnację biskupa Seo de Urgell.

Demokratyzacja miała miejsce dzięki wielu czynnikom, wśród których nie można nie wspomnieć o zaangażowaniu kolejnych współksiążąt w ten proces. Doprowadziło to do kolejno: przyznania kobietom czynnego prawa wyborczego (współksiążęta wyrazili na to zgodę w 1970 r.), przyznania biernego prawa wyborczego, przyznanie formalnej równości kobiet i mężczyzn wobec prawa (1975 r.), obniżenia cenzusu wieku, a także wydania zgody na zainicjowanie reform instytucjonalnych, których efektem jest kształt dzisiejszego systemu politycznego (Osóbka, 2009: 188). Reformy instytucjonalne bez wątpienia nie byłyby możliwe, gdyby nie było pozytywnego nastawienia ze strony obu współksiążąt. W 1978 r. Valéry Giscard d'Estaing i bp Joan Martí i Alanís spotkali się z okazji siedemsetnej rocznicy zawarcia Pareatge i zainicjowali cały proces reform które przebiegały stopniowo przez ponad 20 lat od przełomu lat 70. i 80. do uchwalenia obecnie obowiązującej ustawy zasadniczej. 
Kolejni prezydenci francuscy wspierali reformy, czego przejawem były kolejne akty prawne delegujące władzę z podmiotów współksiążęcych na Radę Generalną (parlament) i zależną od niej Radę Wykonawczą (a już nie od głowy państwa). François Mitterrand w 1986 roku w swoim przemówieniu do członków obu tych organów stwierdził, że żałuje że nie mógł wcześniej doprowadzić do zmian instytucjonalnych (Allocution prononcée, 1986). Było to niejako w opozycji do początkowego stanowiska współksięcia episkopalnego, który w 1962 roku zablokował reformę samorządową (Ray, 1962: 20).

Warto w tym miejscu zwrócić uwagę na postawę francuskiego współksięcia względem przemian ustrojowych w Andorze. O ile biskup Joan Martí i Alanís domagał się przede wszystkim zagwarantowania głowie państwa możliwości odrzucenia traktatów, które ograniczałyby kompetencje głowy państwa, o tyle François Mitterand zwracał uwagę na inny aspekt przyszłej konstytucji i całej konstrukcji ustroju Andory. Francuski prezydent opowiadał się przede wszystkim za wykrystalizowaniem się jasnej sytuacji prawnomiędzynarodowej pirenejskiego księstwa i zapewnieniem mu uznania jako państwa, pełnoprawnego członka społeczności międzynarodowej (Baró Solà, 2005: 68-72). Ostatecznie na początku 1993 r. posłowie opowiedzieli się za projektem ustawy zasadniczej, w kwietniu pod jej tekstem swoje podpisy złożyli obaj współksiążęta, a niedługo później nowy status Księstwa został zatwierdzony przez Andorczyków w referendum, w efekcie czego 4 maja Konstytucja Księstwa Andory weszła w życie (Report, 1989: 2).

\section{STATUS ANDORY PRZED RATYFIKACJĄ TRANTATU I PRZED PRZYJĘCIEM KONSTYTUCJI KSIĘSTWA}

Ustalenie statusu Andory sprzed 1993 r. stanowi dla badaczy prawa międzynarodowego niemały problem. Jedynym przymiotnikiem, co do którego prawie wszyscy (o ile nie wszyscy) badacze byli i są zgodni, to określenie Kraju Dolin jako terytorium zależnego. W literaturze znajduje się wiele terminów określających ówczesną Andorę: kondominium, niekolonialne terytorium zależne, terytorium półsuwerenne, terytorium wasalne (Cybulski, 2008: 240; Kwiecień, 2004: 135). Kwestia ustalenia statusu Andory stała się przedmiotem bardzo ciekawego, z punktu widzenia naukowego, problemu reprezentowania Kraju Dolin na arenie międzynarodowej, a poprzez to wielokrotnie odciskała swoje piętno na stosunkach andorsko-francuskich w drugiej połowie XX wieku.

Jedną z najważniejszych kwestii, jaką należy w tym miejscu wskazać, jest formuła, skład andorskiej głowy państwa. Panami Andory byli ex officio biskup Seo de Urgell oraz każdy kolejny hrabia Foix. Sytuacja pozornie skomplikowała się z chwilą przejścia praw zwierzchnich nad Andorą z hrabiów Foix na kolejnych królów francuskich. Nie oznaczało to jednak, że prawa osobiste monarchy francuskiego przeszły automatycznie na prawa państwa francuskiego (nawet jeśli przywołalibyśmy słynne słowa absolutystycznego króla Ludwika XIV). Takie stanowisko potwierdza chociażby fakt, że późniejsze akty prezydenta Republiki dokonywane przezeń w charakterze współzwierzchnika Andory nie były (i nadal nie sa) aktami władzy francuskiej i nie mogły być anulowane przez Radę Państwa (Sikorska, 1971: 88). 
Kolejną kwestią wartą zauważenia jest płacona quèstia niemal nieprzerwanie stanowiąca początkowo faktyczną daninę, a później już jedynie symboliczną formę zależności Andorczyków od panów francuskiego i episkopalnego (w pewnym okresie danina pieniężna przekazywana współzarządcy francuskiemu miała być ekwiwalentem wartości dwóch sztuk: koni, świń, byków i kóz, co można uznać za daninę symboliczną) (Bladé, 1882: 21). Płacenie jej ustało wraz z zawarciem trójstronnego traktatu i przyjęciem ustawy zasadniczej.

O stosunkach francusko-andorskich w większym zakresie można mówić dopiero od początku ubiegłego stulecia, kiedy to rozwinięto politykę infrastrukturalną Kraju Dolin. To właśnie budowa dróg łączących Andorę z regionami francuskimi pozwoliło na większy przepływ ludności francuskiej do Księstwa i andorskiej do pobliskich regionów francuskich. Trwającą ponad 40 lat budowę drogi, łączącej andorskie miasto na granicy z Francją Pas de la Casa z położonym w głębi kraju andorskim Soldeu, została ukończona w latach 30. XX wieku. Na przełomie lat 20. i 30. XX wieku podjęto decyzję o rozbudowie elektrowni wodnej, co było możliwe dzięki trójstronnemu porozumieniu Andory z jej sąsiadami, a w 1930 r. podpisano umowę administracyjną z urzędami pocztowymi Francji i Hiszpanii w sprawie wydawania własnych znaczków w Księstwie. Wszystkie te wydarzenia w sposób bezsporny wpłynęły na większe otwarcie się Andorczyków na procesy zachodzące w Europie (Kucała, 2007: 48-49).

W najnowszej historii politycznej Księstwa w kontekście stosunków andorsko-francuskich nie sposób nie wspomnieć o roszczeniach francuskich do wyłącznego prawa reprezentowania Andory na arenie międzynarodowej, które spotkały się ze zdecydowanym sprzeciwem współksięcia episkopalnego. W 1952 r. Księstwo stało się stroną Powszechnej Konwencji o Prawie Autorskim, która była pierwszym międzynarodowym porozumieniem, którego sygnatariuszem była Andora. W procesie przyjmowania tego aktu strona francuska wyraziła sprzeciw, który jednak nie był skuteczny. Ostatecznie strona francuska porozumiała się ze współksięciem episkopalnym, dzięki czemu w styczniu 1953 r. oświadczono, że od końca poprzedniego roku Andora stała się stroną Konwencji (31 grudnia dokumenty ratyfikacyjne zostały złożone przez współksięcia biskupa, a 23 dni później dokumenty złożył współksiążę francuski) (Sroka, 2010: 208; Protocol 3 annexed: 2-5).

Kilkanaście miesięcy później konflikt między oboma współksiążętami rozgorzał na nowo. Francuski minister spraw zagranicznych odmawiając biskupowi Seo de Urgell i reprezentującej go delegacji hiszpańskiej prawa do reprezentowania Andory w liście do sekretariatu ONZ wprost stwierdził, że reprezentowanie Andory przez delegację hiszpańską jest niedopuszczalne. W odpowiedzi na to, bp Ramón Iglesias i Navarri potwierdził swoje prawa do współzarządzania Andorą oraz odmówił ratyfikacji Konwencji, a w liście do Dyrektora Generalnego UNESCO potwierdził zasadę dwuosobowego zarządu nad Księstwem, odmawiając stronie francuskiej prawa do skorzystania z klauzuli dotyczącej kolonii (art. 35 Konwencji), wobec czego Andora nie stała się stroną tego aktu prawa międzynarodowego (Duursma, 1996: 355). Argumentem, którym bez wątpienia mogła posługiwać się strona francuska to kwestia sprawowania opieki nad obywatelami andorskimi, która to była do $1993 \mathrm{r}$. sprawowana przez francuskie służby konsularne (Sikorska, 1971: 88). 
Kiedy w 1971 r. zwołano w Paryżu konferencję w celu rewizji Konwencji do jej obrad, dopuszczono zarówno francuską, jak i hiszpańską delegację, które posiadały prawo reprezentowania stanowisk obu współksiążąt. Jednak delegacja francuska postanowiła po raz kolejny poddać $\mathrm{w}$ wątpliwość prawo delegacji hiszpańskiej do reprezentowania współksięcia episkopalnego. Wobec braku rozstrzygnięcia porozumienia między stronami Andora została poza postanowieniami paryskiej konferencji (Duursma, 1996: $355)$.

Bez wątpienia konflikt między oboma współksiążętami negatywnie wpływał na otwieranie się Andory na zewnątrz. Nie należy jednak zapominać o działaniach współksięcia francuskiego, które wspierały ten proces. Poza wspomnianym wcześniej wsparciem dla reform instytucjonalnych, warto wspomnieć o podróży francuskiego współksięcia do Andory. W październiku 1967 r. po raz pierwszy w dziejach Księstwa w podróż do Andory udał się francuski prezydent Charles de Gaulle, na co nie zdecydował się żaden z jego 46 poprzedników (Andorra. Toter, 1967; Andorra: The Day, 1967).

Nie podlega wątpliwości, że rok 1993 dla Andory był wyjątkowy: poza przyjęciem pierwszej ustawy zasadniczej, podpisaniem i ratyfikowaniem trójstronnego traktatu stanowiącego przedmiot niniejszego artykułu, Zgromadzenie Ogólne Organizacji Narodów Zjednoczonych dokładnie trzy miesiące po wejściu w życie Konstytucji Księstwa, zaakceptowało projekt rezolucji o przyjęciu Andory jako 184 państwa członkowskiego tej organizacji (U.N. Makes Room, 1993). Księstwo miało legalną legitymację do bycia traktowanym na równi ze swoimi większymi terytorialnie sąsiadami.

\section{GRANICA ANDORSKO-FRANCUSKA}

Kwestia granicy andorsko-francuskiej nie doczekała się w literaturze analizy, pomimo dość ciekawej sytuacji tej granicy po 1993 r. Na początku warto wspomnieć przede wszystkim, że granica ta nie stanowiła przedmiotu większych sporów między sąsiadami. Wynikało to zapewne z kilkukrotnie wskazywanego już wcześniej z niewielkiego przepływu ludności do i z Andory do państw ościennych. W historii, poza incydentem związanym z wkroczeniem żandarmów francuskich na początku XX wieku, wspomina się wydarzenia ze stulecia XIX kiedy to doszło do konfliktu między sąsiadami. W jego efekcie rozważano nawet pomysł wybudowania muru mającego stanowić widoczną granicę między terytorium Andory a terytorium państwa francuskiego. Ostatecznie termin zarzucono ze względu na koszty budowy i niemożliwość zrealizowania tego planu w określonym czasie (Another war, 1884).

W związku z coraz liczniejszą grupą obywateli francuskich przekraczających granicę z Andorą w XX wieku (a w szczególności w drugiej jego połowie), już w $1970 \mathrm{r}$. zawarto porozumienie $\mathrm{w}$ sprawie koordynacji francuskiego i andorskiego systemu zabezpieczenia społecznego. Na mocy tego aktu Andorczycy przebywający we Francji i Francuzi przebywający w Księstwie (wraz z ich rodzinami) będą obejmowani taka samą ochroną systemu zabezpieczenia społecznego. Umowa w bardzo komplementarny sposób regulowała sytuację, gdyż znalazły się w niej odniesienia do świadczeń z tytułu macierzyństwa, choroby i śmierci pracownika, a także przekroczenia wieku emerytalnego i niepełnosprawności (Arrangement général relatif, 1970). Rosnąca licz- 
ba osób przekraczających granicę andorsko-francuską musiało wreszcie doprowadzić do jej przebudowy, by umożliwić łatwiejsze połączenia między regionami francuskimi a Księstwem. Do końca XX wieku Andorę z Francją łączyło praktycznie tylko jedno połączenie drogowe.

Kolejne lata nie zmieniały nic w kształcie granicy andorsko-francuskiej, aż do początku XXI stulecia. W lipcu $2001 \mathrm{r}$. wszedł w życie traktat o korekcie granicy państwowej. Miał on doprowadzić do poprawy ruchu drogowego między francuską miejscowością Porta i parafią Encamp w Andorze. Granica miała ulec zmianie ze względu na stale rosnącą liczbę pojazdów przekraczających granicę z Francją (w 1993 r. tych pojazdów było 2033 050, a siedem lat później aż 2901 750). Wśród powodów wymieniano też względy bezpieczeństwa (dotychczasowa trasa była bardzo kręta i w zimę często zasypywana) i opłacalności (nowa trasa miała być dużo krótsza) (Rapport fait, 2001: 3-8).

W początkowym procesie ratyfikacji odpowiedniej umowy międzynarodowej władze francuskie zwróciły uwagę, że przebieg granicy andorsko-francuskiej nie jest wynikiem jakiegokolwiek aktu o charakterze polityczno-prawnym, a wynika tylko i wyłącznie ze zwyczaju („La frontière résulte de la coutume”) i osiemnastowiecznych decyzji sądów francuskich (Rapport fait, 2001: 3-8). Ostatecznie rządy zobowiązały się do wymiany $15595 \mathrm{~km}^{2}$ swoich terytoriów. Na terytorium oddanym przez Francję miano usprawnić dostęp do tunelu pod Envalirą poprzez budowanie wiaduktów i nasypów. Andora zobowiązała się do połączenia budowanego wiaduktu $\mathrm{z}$ francuską siecią drogową na własny koszt. Obie strony zobowiązały się wyznaczyć delegatów, którzy będą odpowiedzialni za wytyczenie nowej linii granicznej (Traité entre la République, 2000). Traktat wszedł w życie dopiero 26 lipca 2001 r., co doprowadziło do przełożenia terminu otwarcia tunelu na maj, a później na sierpień następnego roku (Rapport fait, 2001: 7-8). Ostatecznie tunel otwarto. W związku z tym, że spośród wszystkich sąsiadów Francji, tylko z Andorą nie posiada ona umowy określającej dokładny przebieg granicy i dlatego konieczne wydaje się określenie granicy w bilateralnym traktacie (Coopération transfrontalière), co będzie zapewne przedmiotem rozmów obu stron w niedalekiej przyszłości.

Otworzony tunel pozwolił na zwiększenie przepływu ludności na granicy francusko-andorskiej, co musiało doprowadzić do zawarcia w 2002 r. konwencji, na mocy której przekraczanie tej granicy miało być szybsze, a kontrole graniczne miały działać bardziej efektywnie (Edicte del 27-2-2004 pel, 2004). Tym samym weszły w życie plany zapowiadane jeszcze przez Valéry'ego Giscarda d'Estaing (a popierane później chociażby przez Jacquesa Chiraca), który w 1978 r. wskazywał na konieczność wprowadzenia udogodnień infrastrukturalnych na granicy między państwami (Allocution, 1978).

\section{TRÓJSTRONNY TRAKTAT O DOBRYM SĄSIEDZTWIE, PRZYJAŹNI I WSPÓŁPRACY}

O ile relacje między Andorą a Hiszpanią i Francją po 1993 r. są uregulowane przede wszystkim poprzez porozumienia, traktaty i umowy międzynarodowe, o tyle okres 
przed przyjęciem ustawy zasadniczej Księstwa i zawarcia trójstronnego traktatu opierał się na różnego rodzaju bilateralnych porozumieniach administracyjnych lub jednostronnych aktach administracyjnych. Wynikało to przede wszystkim ze zdecydowanej odmowy uznania Andory przed 1993 rokiem za suwerenne państwo, z którym można byłoby podpisać umowę międzynarodowa, a której sygnatariuszami, jak twierdzili Francuzi i Hiszpanie, mogą być wyłącznie państwa suwerenne, co zostało już wcześniej wspomniane (Report on the situation, 1989: 24).

Fundamentalną, z punktu widzenia stosunków Andory z jej sąsiadami, jest trójstronny „, o dobrym sąsiedztwie, przyjaźni i współpracy między Księstwem Andory, Republiką Francuską i Królestwem Hiszpanii z 1993 r. (fr. Tractat de bon veïnatge, amistat i cooperació entre el Principat d'Andorra, el Regne d'Espanya i la República Francesa) (dalej jako: Traktat o dobrym sąsiedztwie). Został on podpisany 1 czerwca 1993 r. w Paryżu przez francuskiego ministra spraw zagranicznych Alaina Juppé i w Madrycie przez hiszpańskiego ministra spraw zagranicznych Javiera Solanę Madariaga, a dwa dni później przez andorskiego szefa rządu Òscara Ribasa i Reiga. 4 listopada tego samego roku został zatwierdzony przez Radę Generalną i wszedł w życie 1 grudnia $1994 \mathrm{r}$.

Wszystkie trzy strony umowy zobowiązały się do poszanowania wzajemnych interesów i współpracy w celu rozwiązywania wszelkich trudności, które mogą pojawić się w przyszłości (w tym również w sprawach kontaktów sąsiadów Księstwa działających jako państw członkowskich Unii Europejskiej, o czym później). W przypadku, gdy Andora zawiera umowę z Hiszpanią lub Francją informacja o tym fakcie musi zostać przekazana ścieżką dyplomatyczną trzeciemu państwu nieuczestniczącemu w danym porozumieniu. Księstwo zobowiązało się do nie podejmowania działań mogących wpływać na bezpieczeństwo wewnętrzne lub zobowiązania międzynarodowe któregokolwiek z sąsiadów. Traktat przewidział szereg obowiązków spoczywających na Hiszpanii i Francji, niemniej najważniejszym jego postanowieniem było bez wątpienia uznanie Andory za suwerenne państwo. Ponadto, na mocy tego aktu sąsiedzi Księstwa:

- ustanowili stosunki dyplomatyczne z Andorą;

- uznali niepodzielność jej terytorium, a w przypadku jego naruszenia (lub nawet zagrożenia naruszenia) zobowiązali się do przeprowadzenia $\mathrm{z}$ andorskim rządem konsultacji co do użycia odpowiednich środków w celu zapewnienia owej niepodzielności;

- zobowiązali się do ułatwiania Andorze udziału w konferencjach i organizacji międzynarodowych;

- zobowiązali się do ochrony interesów Andory, reprezentacji dyplomatycznej w państwach trzecich oraz w konferencjach i organizacjach międzynarodowych, których Księstwo chce uczestniczyć;

- zobowiązali się do sprawowania opieki nad obywatelami Księstwa w państwach, w których Andora nie ma reprezentacji konsularnej, a takową posiada Hiszpania lub Francja.

W 2000 roku wszystkie trzy strony zdecydowały się podpisać kolejne dwa porozumienia. Pierwsze dotyczyło sprawy wjazdu, tranzytu, pobytu i osiedlania się obywateli państw sygnatariuszy. Drugie porozumienie dotyczyło tranzytu i pobytu w Andorze obywateli państw trzecich. 
Na mocy pierwszego porozumienia obywatele Andory, Francji i Hiszpanii, wraz z najbliższą rodzina, mają prawo bezwizowego pobytu na swoich terytoriach przez 90 dni. Po upłynięciu tego terminu obywatele zobowiązani są do uzyskania pozwolenia na pobyt. Porozumienie umożliwiło dostęp uczniów i studentów do szkół sygnatariuszy, a pracowników do miejsc pracy sygnatariuszy z zastrzeżeniem miejsc pracy w sektorze publicznym. Umożliwiono też zastosowanie klauzuli, wedle której obywatel któregokolwiek z trzech sygnatariuszy może zostać wydalony ze względów porządku publicznego, bezpieczeństwa lub zdrowia publicznego. Umowa została zawarta 4 grudnia 2000 roku w Brukseli na czas nieokreślony.

W bardzo zbliżony sposób skonstruowano drugą umowę, która została zawarta tego samego dnia. Strony konwencji zobowiązały się do koordynowania swojego ustawodawstwa w sprawach wjazdu i pobytu obywateli państw trzecich i regularnego informowania się o liście państw trzecich, których obywatele są zobowiązani do posiadania wizy na pobyt trwający mniej niż 90 dni. Gdyby cudzoziemiec chciał swój pobyt przedłużyć, zobowiązany jest on do złożenia odpowiedniego wniosku do władz andorskich. Konwencja wskazała określone postępowanie w stosunku do obywateli państw członkowskich UE i EOG. Konwencję zawarto na okres 5 lat, jednak postanowiono, że będzie corocznie odnawiana, jeżeli żadna ze stron nie wyrazi wcześniej sprzeciwu.

\section{DWUSTRONNE STOSUNKI W LATACH 1993-2013 ORAZ STOSUNKI Z UNIĄ EUROPEJSKĄ}

19 marca 1993 r. strony zawarły umowę w dziedzinie edukacji (Conveni entre el Govern, 1993). Umowa ta stanowiła podstawę funkcjonowania francuskiego systemu edukacji w ramach systemu edukacji przedszkolnej, podstawowej i średniej pod zarządem parafii Księstwa. Na ten problem zwracał uwagę podczas swojej podróży do Andory współksiążę Charles de Gaulle (Allocution prononcée, 1967). Dzięki niej nastąpiło też zrównanie systemów edukacji. Na mocy tej umowy możliwe było utworzenie kolejnych szkół andorsko-francuskich. Przedmiotem umowy jest jednak przede wszystkim status pracowników szkół francuskich w Księstwie. W 1997 r. weszło w życie porozumienie ministrów oświaty, którzy uzgodnili uznanie dyplomu andorskiej szkoły ponadpodstawowej oraz wzajemnego uznawania francuskiego i andorskiego egzaminu maturalnego. Wobec sukcesu porozumienia z 1993 r. i upłynięcia okresu jego obowiązywania 10 lat później, 24 września 2003 r. ministrowie ds. edukacji narodowej Francji i Andory zdecydowali o podpisaniu nowej umowy na kolejne 10 lat, której głównym założeniem jest wzmocnienie sfer współpracy. W 2007 r. ministrowie, odwołując się do zapisów umowy z 2003 roku, podpisali porozumienie w celu wprowadzenia równoważności dyplomów.

Andora zawarła z Francją szereg szczegółowych umów międzynarodowych:

- w sprawie technicznej współpracy i wzajemnej pomocy w sprawach cywilnych oraz współpracy andorskich służb pożarniczych z francuskimi zespołami ratowniczymi podczas ich interwencji poza terytorium Francji w przypadku klęski żywiołowej (Acord entre el Principat d'Andorra i el Govern de la República Francesa relatiu a la cooperació tècnica i a l'assistència mútua en matèria de cooperació civil i a la 
integració des bombers andorrans en els equips de socors francesos durant les seves intervencions fora del territori francès en el cas de catŕstrofes naturals o d'accidents tecnologics majors);

- w sprawie przejezdności przygranicznych dróg w okresie zimowym (Arranjament de cooperació per a la viabilitat hivernal a les carreteres frontereres entre el ministre d'Ordenament Territorial del Principat d'Andorra i el ministre encarregat de l'Equipament i dels Transports de la República Francesa);

- w sprawie monitorowania jakości powietrza (Conveni per a la vigilància de la qualitat de l'aire);

- w sprawie uznawania prawa jazdy (Edicte del 24-1-2007 pel qual es fa públic l'Intercanvi de notes constitutiu d'Acord entre el Govern del Principat d'andorra i el Govern de la República Francesa sobre el reconeixement i l'intercanvi de permisos de conduir);

- w 2000 r. zawarto kolejne porozumienie w sprawie zabezpieczenia społecznego (weszło ono w życie 1 czerwca 2003 r.);

- w 2003 r. zawarto konwencję w sprawie współpracy administracyjnej. Była ona potrzebna do określenia statusu urzędników zależnych od francuskiego systemu administracji publicznej (tj. francuskich sędziów i funkcjonariuszy publicznych) oraz warunków w jakich mogą oni otrzymać pracę w Księstwie (Edicte del 10-3-2003 pel qual es fa públic que el Conveni entre el Govern del Principat d'Andorra i el Govern de la República Francesa relatiu a la Cooperació Administrativa entrarà en vigor l'1 d'abril del 2003);

- w 2005 r. podpisano porozumienie administracyjne między ministrami w sprawach sportu;

- 21 sierpnia 2006 r., po pięcioletnim okresie ratyfikacji, weszła w życie zawarta między rządami Andory i Francji umowa dotycząca międzynarodowego przewozu towarów (Edicte del 24-8-2006 pel qual es fa públic que l'Acord entre el Govern de la República Francesa i el Govern del Principat d'Andorra relatiu als transports internacionals de mercaderies per carretera ha entrat en vigor el 21 d'agost del 2006);

- w 2009 r. Andora zawarła z Francją porozumienie w sprawach wymiany informacji podatkowej.

Stosunki Andory z Unią Europejską odgrywają fundamentalną rolę przede wszystkim ze względu na bardzo ożywione stosunki gospodarcze (w 2008 roku eksport i import z Unią Europejską wyniósł kolejno 96\% i 91\%) (Andorra Bàsica, 2008: 28). Podpisanie przez Francję w 1951 r. traktatu paryskiego powołującego do życia Europejską Wspólnotę Węgla i Stali nie miało większego wpływu na status Andory. Stąd temat ten nie będzie stanowił zasadniczego przedmiotu niniejszego artykułu, gdyż dopiero przystąpienie Hiszpanii do struktur wspólnotowych odegrało swoją rolę na polityce wewnętrznej i zagranicznej Księstwa. Po akcesji Królestwa Hiszpanii, Wspólnota Europejska oraz władze Andory postanowiły o konieczności uregulowania wzajemnych stosunków. Po trwających niewiele ponad rok negocjacjach, porozumienie podpisano w Luksemburgu 28 czerwca 1990 r. Było to pierwsze w dziejach Andory porozumienie mające charakter umowy międzynarodowej (Kwiecień, 2004: 135).

Ludność Księstwa do 2002 r. posługiwała się francuskimi i hiszpańskimi środkami płatniczymi (tj. frankami francuskimi i pesetami hiszpańskimi), były to jednak środki 
płatnicze jedynie de facto, a nie de iure, gdyż Andora nigdy nie miała prawnie uregulowanego środka płatniczego. $Z$ dniem przyjęcia przez Hiszpanię i Francję euro jako pełnoprawnego środka płatniczego na ich terytorium w tym samym trybie jak miało to miejsce przed 2002 rokiem Andora przyjęła nowy środek płatniczy. Rada Generalna w październiku 2000 r. przyjęła odpowiednią ustawę, która miała regulować przyjęcie 1 stycznia 2002 r. euro jako środka płatniczego (Lei reguladora, 2000). Ów akt jednostronny musiał zostać wydany w związku z tym, że nie doszło do wcześniejszego unormowania tej kwestii w dwustronnym porozumieniu zawartym między Księstwem a Wspólnota, a mennice narodowe Hiszpanii i Francji były zobowiązane do stopniowego wycofywania walut narodowych.

Rząd Andory, chcąc doprowadzić do unormowania sytuacji środka płatniczego w Księstwie oraz w reakcji na naciski ze strony Unii Europejskiej, w 2004 r. doprowadził do zawarcia porozumienia w sprawie opodatkowania dochodów z tytułu oszczędności. Mimo, że Andora już w 2003 roku wystąpiła do Wspólnoty o zawarcie odpowiedniego porozumienia monetarnego, które umożliwiłoby Księstwu korzystanie z euro jako pełnoprawnego środka płatniczego na jego terytorium, a Rada UE rok później upoważniła Komisję do rozpoczęcia negocjacji z Księstwem (Decyzja Rady, 2004), to dopiero w 2011 roku udało się zawrzeć odpowiednią umowę. Porozumienie weszło w życie 1 kwietnia 2012 roku.

Układ monetarny upoważnia Księstwo do emisji 2,4 mln monet euro (prawo emisji banknotów Andorze nie przysługuje) od 1 lipca 2013 roku. Prawo emisji będzie wykonywane przez wskazaną przez rząd Andory mennicę znajdującą się w UE, która ma doświadczenie w produkcji monet euro. Zdecydowano, że Andora będzie mogła emitować funkcjonujące w obiegu od kilkudziesięciu lat monety kolekcjonerskie, które nie będą miały funkcji środka płatniczego. Układ zobowiązał Księstwo do wdrożenia szeregu aktów prawnych tj. tej części acquis communautaire, która reguluje emisję i funkcjonowanie euro określając, że część z nich musi wejść w życie już w 12 miesięcy, a pozostałe w 18 miesięcy, 4 lub 6 lat od dnia wejścia w życie układu (Układ monetarny, 2011).

$$
* * *
$$

Andora, będąca w ostatnich latach miejscem poszukiwania pracy przez wielu Francuzów, Hiszpanów i Portugalczyków nie mogła pozostać obojętna na zachodzące procesy. Stąd zauważalna jest współpraca andorsko-francuska w sprawach przepływu ludności, czego rezultatem były porozumienia w sprawach zabezpieczenia socjalnego pracowników, edukacji, podatków. Warto również wspomnieć, że przedmiotem bilateralnych umów jest przebudowa infrastruktury drogowej, która w przypadku przejść granicznych z oboma państwami była konieczna, a która była spowodowana systematycznie zwiększającą się liczbą turystów przekraczających granice Andory z Francją i Hiszpanią.

Księstwo, otwarte na pracowników-cudzoziemców, przez wiele lat pozostawało dla wspomnianych już wcześniej Hiszpanów, Francuzów i Portugalczyków miejscem, w którym, wobec modernizacji infrastrukturalnych i rozwoju sektora usług (w tym przede wszystkim bankowości i turystyki) rósł popyt na pracowników spoza teryto- 
rium Andory. Efektem tego była szeroka fala migracji, co musiało skutkować uregulowaniem statusu prawnego tych pracowników.

Swego rodzaju cieniem na stosunki Andory z Francją i Unią Europejską kładzie się kwestia porozumienia w sprawie posługiwania się walutą europejską. Kolejne starania rządu andorskiego wyrażone w umowie w sprawie opodatkowania dochodów z tytułu oszczędności z 2004 roku, umowie o współpracy z 2005 roku, powołanie do życia organu odpowiedzialnego za ochronę danych osobowych w 2010 roku, doprowadziły do podpisania porozumienia w kwestiach stosunków walutowych w 2011 roku, czyli po dziewięcioletnim okresie bezprawnego korzystania z euro przez Andorczyków.

Przedmiotem stosunków andorsko-francuskich są obecnie kwestie związane z reformą podatkową w Andorze oraz miejscem francuskiego systemu edukacji w szkolnictwie Księstwa, a także poprawa relacji dwustronnych po negatywnie odbieranej groźbie zrzeknięcia się tytułu współksiążęcego przez byłego prezydenta Nicolasa Sarkozy'ego (Minder, 2010). Jeżeli spojrzy się na kwestię stosunków między trzema państwami poprzez pryzmat aktów prawnych, warto wskazać, że o ile stosunki hiszpańsko-andorskie były regulowane głównie poprzez umowy bilateralne w postaci konwencji lub porozumień, o tyle Francja regulowała swoje stosunki z sąsiadem w drodze aktów jednostronnych (przede wszystkim dekretów głowy państwa), a najważniejszym aktem regulującym obecny fundament stosunków andorsko-francuskich jest bez wątpienia trilateralny traktat z 1993 roku i, co nie może zostać pominięte, Konstytucja Księstwa, która w szczególny sposób traktuje głowę państwa francuskiego.

Warto wreszcie wspomnieć o tym, że wobec krytyki ze strony OECD i sąsiadów, Andora w 2009 roku zaczęła przystępować do szeregu bilateralnych porozumień w sprawie wymiany informacji podatkowej (tzw. Tax Information Exchange Agreements). W okresie 2009-2012 Księstwo podpisało lub ratyfikowało 20 tego typu umów (Agreements - Andorra).

Podsumowując, stosunki międzynarodowe Księstwa najintensywniej przebiegają w relacjach sąsiedzkich: z Hiszpanią i Francją. Wynika to w sposób oczywisty z położenia geograficznego Księstwa, jednak w sposób wyjątkowo istotny również z konstrukcji andorskiego systemu politycznego. Pozostawanie w orbicie wpływów Hiszpanii i Francji miało swój przejaw chociażby w prośbie wyrażonej przez Andorczyków, którzy domagali się od Napoleona Bonaparte, przywrócenia ich zależności feudalnej sprzed rewolucji francuskiej. Sprawowanie zwierzchniej władzy przez współksięcia francuskiego doprowadziło w połowie XX wieku do wysuwania roszczeń wyłącznego prawa reprezentacji Księstwa na arenie międzynarodowej. Aktualnie w stosunkach francusko-andorskich, wobec zmiany osoby pełniącej urząd Prezydenta Republiki Francuskiej - współksięcia francuskiego, dostrzegalna jest stabilizacja.

\section{Bibliografia}

Allocution prononcée par Monsieur Charles de Gaulle Président de la République française et Co-Prince d'Andorre, Andorre la Vielle - Maison des Vallées - 23 octobre 1967 (1967), $\mathrm{http} / /$ www.coprince-fr.ad/index.php?option=com_content\&view=article\&id=12\&Itemid= 13\&lang=fr, 26.08.2012. 
Allocution prononcée par Monsieur François Mitterrand Président de la République française et Co-Prince d'Andorre, Andorre la Vielle - Maison des Vallées - 26 septembre 1986 (1986), http://www.coprince-fr.ad/index.php?option=com_content\&view=article\&id=10\&Itemid= 11\&lang=fr, 20.12.2014.

Andorra Bàsica 2008 (2008), Cambra de Comerç, Indústria i Serveis d'Andorra.

Andorra Delegates Perform Old Rite (1939), „Spokane Daily Chronicle”, 6.07.1939.

Andorra, in Two Days, Loses Its Two Princes (1969), „The New York Times”, 30.04.1969.

Andorra Pays France 2 Years' Rent of \$3.88 (1959), „The New York Times”, 24.04.1959.

Andorra receives Hitler' Guarantee'(1942), „The New York Times”, 16.11.1942.

Andorra: The Day the Prince Came (1967), „Time”, 3.11.1967.

Andorra's Leaders Quit In Dispute Over Taxes (1984), „The New York Times”, 2.05.1984.

Andorra. Toter ehebe dich (1967), „Der Spiegel”, 30.10.1967.

Another war (1884), „The New York Times”, 20.03.1884.

Arrangement général relatif à la coordination des dispositions de sécurité sociale françaises et andorranes (1970), Numéro de l'accord 19700187, date de signature 09/06/1970.

Baró Solà L. (2005), Institucions i sistema politic (la Constitució del Principat d'Andorra, més de 10 anys després), „Àmbits de política i societat”, No. 31.

Bladé J. F. (1882), The Valley of Andorra, Cambridge.

Consell General Principat d'Andorra, Delegacions Internacionals, http://www.consellgeneral.ad/ micg/webconsell.nsf/0/6572BADAD394EE1FC1256BEC004B2D2C, 24.10.2014.

Convencio entre el Reino de España, la República Francesa y el Principado de Andorra, relativo a la circulación y estancia en el Principado de Andorra de nacionales de terceros Estados, hecho „ad referéndum” en Bruselas el 4 de diciembre de 2000, Boletín Oficial del Estado (2003), núm. 153 de 27 de junio de 2003, páginas 24810 a 24811 (2 págs.), BOE-A-2003-12778.

Conveni entre el Govern del Principat d'Andorra i el Govern de la República Francesa en l'àmbit de l'ensenyament (1993), de 19-3-93, núm. 18, 07.04.1993, BOPA.

Cybulski L. (2008), Wspólna Polityka Zagraniczna i Bezpieczeństwa na tle działań zewnętrznych Unii Europejskiej, „Prace Naukowe Uniwersytetu Ekonomicznego we Wrocławiu”, nr 10.

Decyzja Rady z 11 maja 2004 r. w sprawie stanowiska Wspólnoty odnośnie do porozumienia w kwestiach stosunków walutowych z Księstwem Andory (2004), 2004/548/WE, Dz. U. UE L 2004.244.47, 16.07.2004.

Duursma J. C. (1996), Fragmentation and the International Relations of Micro-states: Self-determination and Statehood, Cambridge.

Edicte del 27-2-2004 pel qual es fa públic que el Conveni entre el Principat d'Andorra i la República Francesa relatiu als despatxos de controls nacionals juxtaposats entrarà en vigor l'1 de març del 2004 (2004), núm. 014, 10.03.2004, BOPA.

Fernsworth L. A. (1934), Andorra: The Passing of Europe's Last Feudal State, „Foreign Affairs”, Vol. 12, No. 2.

France Diplomatie, Coopération transfrontalière, La France et Andorre, http://www.diplomatie.gouv.fr/fr/pays-zones-geo/andorre/la-france-et-andorre/, 15.10.2014.

France sends gendarmes to make Andorrans obey (1933), „The New York Times”, 20.08.1933.

French 'invaders' now rule Andorra (1933), „The New York Times”, 21.08.1933.

Global Forum on Transparency and Exchange of Information for Tax Purposes, Agreements - Andor$\mathrm{ra}$, http://www.eoi-tax.org/jurisdictions/AD\#agreements, 15.10.2014.

Kaffka A. (2009), El rei rus d'Andorra: fantasies i fets, „Papers de Recerca Històrica”, Vol. 6.

Kucała D. (2007), Historia Andory, w: Historia matych krajów Europy, red. J. Łaptos, Wrocław. 
Kwiecień R. (2004), Suwerenność państwa. Rekonstrukcja i znaczenie idei w prawie międzynarodowym, Kraków.

Leary L. G. (1912), Andorra, the hidden republic, New York.

Llei reguladora de les mesures per garantir la transició cap a l'euro al Principat d'Andorra, d'11-10-2000 (2000), núm. 65, 08.11.2000, BOPA.

Mateu M., Luchaire F. (1999), La Principauté d'Andorre: hier et aujourd'hui, Paris.

Minder R. (2010), Adding Taxes, Shedding Secrecy, „The New York Times”, 27.08.2010.

Moses B. (1893), The Republic of Andorre, New Haven.

Osóbka P. (2009), Andorskie doświadczenia, czyli o pokojowym rozwiazywaniu konfliktów politycznych, „Przegląd Naukowy Disputatio”, t. IX.

Protocol 3 annexed to the Universal Copyright Convention concerning the effective date of instruments of ratification or acceptance of or accession to that Convention, UNESCO, http://unesdoc.unesco.org/images/0018/001855/185500eb.pdf.

Rapport fait au nom de la Commission des Affaires Étrangéres sur le Projet de Loi, adopté par le Sénat, autorisant la ratification du Traité entre la République française et la Principauté d'Andorre portant rectification de la frontière (2001), Document mis en distribution le 26 juin 2001, №3163, Assemblée Nationale, Constitution du 4 Octobre 1958, Onziéme Législature, Enregistré à la Présidence de l'Assemblée nationale le 20 juin 2001.

Ray A. (1962), New Broom in Andorra, „New Leader”, 1.10.1962.

Report on the application by the Principality of Andorra for membership of the Council of Europe (Rapporteur: Mr Reddemann, Germany, Group of the European People's Party) (1994), Doc. 7152, 1403-13/9/94-7-E, 15.09.1994.

Report on the situation in Andorra (1989), Parliamentary Assembly of the Council of Europe, Doc. 6146, 16/11/1989.

Rodríguez M. (2009), Bartumeu vol la tramitació «urgent» de la llei d'intercanvi d'informació, „el Periòdic d'Andorra", 31.07.2009.

Shepherd's Suffrage (1941), „Time”, 20.10.1941.

Sikorska B. (1971), Sytuacja prawnomiędzynarodowa europejskich państw karlowatych, „Sprawy Międzynarodowe", $\mathrm{nr} 4$.

Sroka A. (2010), Państwo karłowate a Unia Europejska - kazus Andory, w: Pierwsza pięciolatka. Mate państwa Europy Środkowo-Wschodniej w Unii Europejskiej, red. R. Żelichowski, Warszawa.

Talk of Other Things (1942), „Time”, 30.11.1942.

Traité entre la République française et la Principauté d'Andorre portant rectification de la frontière, fait à Andorre-la-Vieille le 12 septembre 2000 (2000), numéro de l'accord 20000089, date de signature par la France 12/09/2000.

Tribute (1939), „Time”, 17.07.1939.

Układ monetarny między Unia Europejskq a Księstwem Andory (2011), 2011/C 369/01, Dz. U. UE C 2011.369.1, 17.12.2011.

U.N. Makes Room for Andorra (1993), „The New York Times”, 29.07.1993.

\section{STRESZCZENIE}

W 1993 roku społeczeństwo Andory zdecydowało o przyjęciu pierwszej w dziejach Księstwa konstytucji. Rok ten był dla tego pirenejskiego państwa również wyjątkowy ze względu na przyjęcie go do ONZ i ze względu na zawarcie trójstronnego traktatu z oboma sąsiadami: Hisz- 
panią i Francją. Zdaniem autora, traktat ten w sposób znaczący wpłynął na pozycję Andory na arenie międzynarodowej i na kolejne dziesięciolecia uwarunkował relacje tego państwa z sąsiadami. Przedmiotem niniejszego artykułu jest próba podjęcia analizy tych stosunków, opierając się na relacjach andorsko-francuskich. Autor stara się wskazać sprawy, które stanowiły dla obu państw przedmiot sporu i kompromisu: oszustwa podatkowe, kwestia granicy czy chociażby waluta euro.

\title{
FRANCO-ANDORRAN RELATIONS IN THE $20^{\mathrm{TH}}$ ANNIVERSARY OF THE SIGNING OF THE TREATY ON GOOD NEIGHBORHOOD, FRIENDSHIP AND COOPERATION
}

\begin{abstract}
In 1993, the society of Andorra decided to accept the first constitution in the history of the Principality. This year was also unique for the Pyrenean state due to the accession to the UN and due to the concluding the trilateral treaty with two neighbors: Spain and France. According to the author, the Treaty has significantly influenced on the position of Andorra in the international arena and for the next decade conditioned the relationship of the state with its neighbors. The purpose of this article is to undertake an analysis of the relationship based on Andorran-French relations. The author tries to identify issues that were the subject matter of the two countries' dispute and compromise: tax fraud, the border issue or even the euro currency.
\end{abstract}


